\title{
THE MEANING OF ETHNIC EQUALITY IN SCANDINAVIAN ANTI-DISCRIMINATION LEGISLATION
}

\begin{abstract}
Ethnicity is an academically contested concept and has multiple meanings in everyday communication. The present article analyses recent Swedish and Norwegian anti-discrimination law reform documents and asks how policymakers debate the meaning of ethnic equality, and the consequence of this debate for the incorporation of preferential treatment regulation in the law. The analysis suggests that ethnicity must be interpreted through a multifaceted lens of 'othering' in order to allow for 'appropriate' distinctions between relevant groups. This raises particularly challenging questions for proactive equality work, a central component of the anti-discrimination legislation in these countries.
\end{abstract}

\section{Keywords}

Ethnicity $\bullet$ equality $\cdot$ discrimination $\cdot$ discourse $\cdot$ policy

Received 12 July 2013; Accepted 11 August 2014

\section{Introduction}

Recent legal reform processes aiming to create unified equal treatment legislation in Sweden and Norway have brought 'ethnic equality' to the political agenda. The establishment of ethnic equality legislation has followed in the footsteps of the countries' gender equality legislation. Gender equality legislation has been particularly strong in these countries, with a solid commitment to positive action. Both Swedish and Norwegian legislation permit preferential treatment, with the explicit purpose of reaching gender balance in several areas of social life (e.g. education and the labour market). Over time, it has become relatively uncontroversial to claim that gender parity cannot be reached through prohibitions against discrimination alone. Positive action, including preferential treatment on the grounds of gender, has broad support among the social partners as well as in the Swedish and Norwegian public sphere.

The inclusion of preferential treatment for ethnic minorities in the legislation has been a matter of debate. There are at least two fundamental differences between gender and 'race' or ethnicity as forms of inequality that have consequences for equality legislation. First, men and women come from families that are equally distributed throughout the economic spectrum (cf. Ridgeway 2011: 9). By contrast, many immigrant or minority groups are disproportionately of lower socioeconomic status, due to past or present experiences with discrimination and exclusion, or migration from less affluent countries. This would, for example, be the case for a number of refugee populations from sub-Saharan Africa, and national minority
Liza Reisel ${ }^{*}$

Institute for Social Research, Oslo, Norway

groups such as the Romani. Gendered inequalities in education or the labour market cannot be attributed to class-based differences to the same extent as for these minority groups. Secondly, there are roughly equal numbers of men and women in the population, and the two genders are relatively easily distinguishable from one another. Gender equality is in this sense a relatively simple outcome to measure. Ethnic equality, on the other hand, is much more complex, both due to its intersection with class and due to the wide range of possible target groups, with varying statuses and numbers. As a consequence, efforts to harmonize equality legislation across discrimination grounds in Sweden and Norway raise pressing questions about the meaning of ethnic equality in the labour market, education and other areas of social life.

In this article, I analyse recent Swedish and Norwegian antidiscrimination law reform documents and ask how the advisory committees and policymakers debate the meaning of ethnic equality, and the consequence of this debate for the incorporation of preferential treatment regulation in the law.

The following section situates the analysis within a broader field of research on anti-discrimination and equality legislation, and outlines previous research on measures to reduce ethnic inequality. Thereafter I present the theoretical framework, with an emphasis on theoretical understandings of equality, legal understandings of preferential treatment and various theoretical and common sense understandings of the concept of ethnicity. This section is followed by a presentation of my methodological and analytical approach. The 
main body of the article consists of a two-part analysis of the policy documents. First, I explore how ethnicity is defined and understood in the policy documents and consequently how these definitions come into play in the discussions about preferential treatment. The article concludes with a discussion about ethnic equality in light of the preceding analyses and the article's theoretical framework. I suggest that to evaluate what constitutes ethnic equality, it is necessary to identify relevant target groups. Yet, as I will show, the identification of appropriate target groups relies on shared common sense understandings of difference or 'otherness'. I argue that this is a particularly problematic characteristic of ethnicity, which distinguishes it from gender in ways that complicate the implementation of proactive measures as means to address ethnic inequality.

\section{Previous research on measures to combat racial or ethnic discrimination}

Internationally, and particularly in the United States, studies of affirmative action have shown that race-sensitive admissions to selective colleges (e.g. Bowen \& Bok 1999; Bowen, Kurzweil \& Tobin 2005), to graduate programmes (Garces 2012) and to employment (Heath 2014) have been effective in creating opportunities for persons of colour. These types of race-based measures have particularly been utilized in national contexts where racial boundaries have historically been clearly delineated, for example through legal definitions of racial difference, with related restrictions on civil rights. In his recent paper on affirmative action policies, Anthony Heath (2014) concludes that what he considers the two most effective western programmes for combatting racial and ethnic discrimination - the American Federal Contract Compliance program and the Northern Ireland Fair Employment programme - were both introduced after major unrest by groups that had long histories of discrimination. This stands in contrast to countries like Norway and Sweden where historical legacies of racial or ethnic discrimination are less apparent.

At the same time, some studies have investigated the legal ambiguity that accompanies affirmative action or equal employment opportunity mandates, and have found that it is often unclear what constitutes compliance with the law (Edelman et al. 1991). The authors argue that the political climate within the organization, together with factors such as the officers' interpretation of the law and their professional aspirations, have important implications for the nature and extent of organizational compliance with affirmative action legislation. Kalev, Dobbin and Kelly (2006) examine the effect of seven common diversity programmes in the United States on increasing the share of women and minorities in management. They find that organizational structures that clearly allocate responsibility for change to specific individuals, committees or task forces are the most effective. The authors attribute the efficiency of these structures to the establishment of accountability, authority and expertise on the issue of diversity within the organization (Kalev, Dobbin and Kelly 2006: 611).

A few studies have also examined how anti-discrimination policies define, address or limit ethnic equality in the European context, most of which focus on EU law (Fredman 2001; Hepple 2004; Mason 2010). Fredman (2001) analyses two central EC directives and UK law, asking what concepts of equality were used and to what extent the provisions were based on an assumption that ethnic groups are fixed and static entities. She argues that direct and indirect discrimination measures are limited in that they are individualistic. This means that they are targeted at individuals who experience discrimination and are dealt with through individual complaints. By contrast, positive duties to promote equality address the structural patterns of inequality proactively, promising to provide social change. She recognizes the particular interactional character of ethnicity and argues that this makes participation of minority groups important in fashioning relevant proactive measures.

Not much research has been conducted on the treatment of ethnic equality in legislation in Norway and Sweden. However, in recent years some studies have emerged that analyse antidiscrimination law from an intersectional perspective, including some research on the legal protection against ethnic discrimination in combination with other grounds, particularly gender (Borchorst et al. 2012; Reisel 2014; Schömer 2012, Skjeie 2009). Although the existing literature analyses and discusses equality measures aimed at ethnic minorities, they do not address the potential tension between equality and difference inherent in proactive equality measures that require explicit delineation of target groups based on racial or ethnic boundaries. Moreover, this question has not been examined in Norway and Sweden where positive action has been included in gender equality legislation since the 1970s. I address these gaps in the literature in the present article.

\section{Equality legislation and ethnicity: a theoretical framework}

\subsection{Equality and anti-discrimination measures}

Fredman (2001) discusses a number of values that inform the principle of equality in various types of equality legislation: neutrality, individualism, autonomy, individual dignity and worth, restitution, redistribution and democracy. She argues that the first three are associated with classic liberal ideals of protection against discrimination. The latter four are associated with a wider understanding of equality - equal right to welfare and a good life, compensation for past discrimination or exclusion, equality of outcome, equal representation and equal decision making power. These aspects of equality may demand a more group-oriented approach to equal treatment than individual claims of discriminatory practice. Heath (2014) also argues that anti-discrimination measures that rely on individuals to come forward with a complaint have proven unsuccessful in eliminating discrimination. Instead, he argues, policies focusing on aggregate outcomes, such as affirmative action legislation or other forms of positive action, are needed to reduce minority underrepresentation.

However, some group-based policies are controversial because they may be perceived as conflicting with the equal treatment principle. British legal professor Hugh Collins has pointed to the dilemma that equal treatment regulates a procedure and not an outcome, which is a source of perpetual tension in anti-discrimination law (Collins 2003: 17). European law, as well as Swedish and Norwegian law, regulates not only equal treatment but also three kinds of deviations from this principle (Collins 2003). The first is circumstances when differential treatment is necessary to avoid direct discrimination, for example, for pregnant women or people with disabilities. The second is when equal treatment leads to indirect discrimination, that is, when a seemingly neutral provision disproportionately excludes parts of the population (e.g. restrictions on headdress). The third concerns preferential treatment, which involves positive discrimination to correct underrepresentation or historical disadvantage. For this final procedure to have legitimacy, it is of central importance that 
the procedure is justified in light of its expected outcome. Ethnic equality is one outcome for which such a provision could be used. The question raised in this article is how policy makers define ethnic equality as an outcome, and to what extent this definition informs their discussion about preferential treatment.

\subsection{Ethnicity as situational and interactional difference}

As we will see, ethnic equality can be challenging to define. A vast body of literature has grappled with the concept of ethnicity. Ethnicity is commonly distinguished from 'race' in that 'race' refers to perceived differences in biological characteristics and ethnicity refers to perceived differences in cultural characteristics. The two concepts are often useful to distinguish for analytical purposes. However, in practice, the distinction between biological and cultural inheritance is not so clear (Hall 2000).

Max Weber's classic definition of ethnic groups has become the starting point for a number of established understandings of ethnicity in more recent scholarship. Weber focused on people's subjective beliefs and collective memories and defined ethnic groups as 'those human groups that entertain a subjective belief in their common descent because of similarities of physical type or of customs or both, or because of memories of colonization and migration' (Weber 1978: 389). Another classic definition is attributed to Fredrik Barth (1969), who emphasized that ethnic membership must be acknowledged by the agents themselves to be socially effective. Ethnicity is thus primarily seen as a social discontinuity more than a cultural one (Eriksen 2002).

However, whereas Barth focused on the internal definition of ethnic groups, resulting in the practice of ethnic boundary maintenance, Richard Jenkins (1997) further distinguishes between internal and external processes of defining an ethnic group. Whereas identifying with in-group members is an integral part of the internal definition process, social categorization plays an important role in the external definition of ethnic groups. Jenkins argues that ethnic identity formation is an on-going process of internal and external definition and that neither of these can be understood in isolation from the other.

These three approaches to the definition of ethnicity are each relevant to the analyses in this paper. Weber's definition emphasizes ethnicity as contextual and socially constructed. Barth's definition highlights the interactional aspect of ethnicity, allowing for the status of individuals and groups to change over time. Finally, Jenkins' definition brings to the fore how ethnic group membership partly depends on recognition by, and the definition power of, surrounding groups. Each of these theoretical perspectives informs an understanding of ethnic group membership as context-sensitive difference, interlinked with social and cultural divisions that may or may not be relevant in a given social situation.

\subsection{Common sense understandings of ethnicity}

Despite these theoretical contributions to our understanding of ethnicity as situational and relational, ethnicity has a tendency to become essentialized in public discourse. Referring to the everyday use of the term 'immigrants', the Norwegian anthropologist Marianne Gullestad (2002) summarized seven hegemonic interpretation frames in the Norwegian immigration discourse; dichotomization, racialization, culturalization, hierarchization, naturalization, everyday nationalism and identity politics. I will argue that these interpretation frames are also applicable to the term 'ethnic minorities' more broadly. When policy makers use the terms ethnic minority, ethnic background or ethnic origin, the terms are implicated with tacit knowledge that is necessary to render them meaningful. Together, Gullestad's seven frames provide a multifaceted lens through which the term 'ethnic minority' can be understood; Dichotomization implies a significant division between 'us' and 'them', indicating two mutually exclusive categories (ethnic minority vs. majority). Racialization implies that ethnicity is most commonly understood as a visible trait. This understanding resonates with Hall's (2000) notion that the binary opposition between the biological meaning of 'race' and the cultural meaning of ethnicity has been disrupted and that the characteristics of ethnicity are commonly viewed as transmitted from generation to generation, not just by culture and education but by biological inheritance (Gunaratnam 2003: 4). Culturalization associates ethnic minorities with a limited range of cultural practices and values, obscuring a wide variety of cultural differences and similarities within the population. Hierarchization implies the subordination of ethnic minority cultural values and practices to some concept of 'national values'. As such, ethnic minorities are defined outside the national selfunderstanding, which is what Gullestad calls everyday nationalism. Naturalization emphasizes the aspects of people's identities that are not a matter of choice, such as their place of birth or kinship ties. Finally, Gullestad argues that identity politics permeate the public debate about immigrants through a deeply polarized rhetoric. Identity politics in this context signifies that the political arguments mainly serve to reaffirm people's position on one or the other side of the debate, rather than attempting to solve problems through real dialogue (Gullestad 2002: 272).

Gullestad's seven interpretation frames make up a multidimensional framework of 'othering' through which a common understanding of the term 'ethnic minority' is established. Interpreting ethnic discrimination as 'othering' may be useful in individual complaints cases, where the context and relations in the relevant situation are given. But if 'othering' is the frame within which the concept of ethnicity makes sense, how do policy makers conceive of the appropriate target groups for proactive measures? This potential dilemma sets ethnic equality measures apart from gender equality measures, in that the question of target groups is a matter of debate. How does this fundamental difference between the two inequality strands influence the deliberations on preferential treatment of ethnic minorities in Norway and Sweden?

\section{Methods and data}

To investigate these questions in the Scandinavian context, I compare policy documents from Norway and Sweden. The analysis is centred on four central advisory reports (or so-called green papers) produced as part of recent anti-discrimination policy reform processes, as well as responses to the documents from policy makers and stakeholders. The documents were selected for analysis because they constitute the foundation for the current ethnic discrimination legislation in the respective countries. The four main documents are:

\section{From Norway:}

1 NOU 2002: 12 Rettslig vern mot etnisk diskriminering (Legal protection against ethnic discrimination).

2 NOU 2009: 14 Et helhetlig diskrimineringsvern (A comprehensive protection against discrimination). 
From Sweden:

3 SOU 1997: 174 Räkna med mångfald! Förslag till lag mot etnisk diskriminering i arbetslivet m.m. (Reckon with diversity! Suggestion for law against ethnic discrimination in the labour market, etc.) .

4 SOU 2006: 22 En sammanhållen discrimineringslagstiftning (A coherent discrimination law).

The documents specifically aim at promoting ethnic equality ('likestilling/jämställdhet') through the expansion of protection against discrimination and proactive equality measures. All four documents were produced by government appointed committees. The first Norwegian committee (1) was appointed by a centrecoalition Government headed by the Christian conservative party. The committee was led by Professor of Law Gudrun Holgersen. It consisted of legal experts from within the Government, as well as from relevant external organizations. The Confederations of Norwegian Enterprise (NHO) and the Norwegian Confederation of Trade Unions (LO) were also represented. The second Norwegian committee (2) was appointed by a left-centre Government headed by the Labour party. The committee was led by Professor of Law Hans Petter Graver. It consisted of experts on inequality on the basis of gender, ethnicity, sexual orientation and disability, most of whom were professors and/or legal experts, in addition to the Director for the Norwegian Directorate for Children and Family Affairs and the Assistant Attorney General. The first Swedish committee (3) was led by legal advisor Margareta Wadstein. The committee mainly consisted of representatives from a number of Swedish labour unions and employers' organizations, most of whom were legal experts; attorneys, legal advisers and ombudsmen. The second Swedish committee (4) was much larger and consisted of parliamentary representatives from all the major parties, legal experts from within the Government, the Ombudsmen for the different discrimination strands and legal advisors from various major Swedish labour unions and employers' organizations. The committee was led by Court of Appeals Judge Göran Ewerlöf. Both of the Swedish committees were appointed by Social Democratic Governments. From this brief description of the four committees, it is clear that each document should be interpreted as the result of negotiations and deliberations within these committees. In some cases, views dissenting from the committee majority are presented as part of the reports.

I analysed the documents by coding them thematically in four stages. At the first stage, I coded all explicit definitions of ethnicity in the texts. Second, I coded the texts according to the seven hegemonic frames comprising Gullestad's multidimensional common sense concept of 'othering', as outlined in the previous section. Third, I identified the parts of the text that discussed equality as an outcome, with particular focus on discussions of preferential treatment of ethnic minorities. Finally, I aligned the discussions of ethnicity and the discussions of preferential treatment in order to investigate to what extent the committees' conceptualizations of ethnicity informed the discussions about preferential treatment, and to what extent a tension between equality and difference could be discerned from the texts. At each stage differences and similarities across the two countries were noted, with two explicit goals: to identify variations in how policy documents in the two countries explicitly and implicitly give meaning to the term 'ethnicity', and whether the two countries (re)produced similar or different discourses about ethnic equality.

\section{The Limits of Preferential Treatment}

In both the Norwegian and Swedish documents, preferential treatment is defined as an exemption from the prohibition against discrimination. Preferential treatment is generally defined as discrimination with the purpose of promoting equality and has been limited by the European court system's judicial practice. The following five limiting principles accompany the preferential treatment regulations: First, it must be used as a measure to promote equality in relation to a specific practical outcome. Secondly, it should be used to improve the position of the underrepresented and disadvantaged group. Thirdly, it may only be used when competing candidates are similarly qualified; implying that quotas or radical preferential treatment is not permitted. Fourth, preferential treatment is limited by the principle of proportionality, which means that in each case the advantages should be weighed against the disadvantages for the person who is discriminated against as a result of the preferential treatment of another. Finally, and most importantly for the present analysis, as soon as equality has been reached, preferential treatment is no longer permitted (cf. NOU 2009:14, p. 59).

This final caveat is particularly central to the question of ethnic equality as an outcome rather than a procedural principle. Due to sensitivity restrictions on the registration of religious affiliation or ethnicity in Norwegian and Swedish public registries (except for membership in religious organizations), both countries rely on country of birth, country of birth of parents and/or citizenship for statistics on their ethnic minority populations (Simon 2012). This restricts the available data on ethnic inequality to immigrants and children of immigrants, constituting only crude approximations of 'racial' or ethnic markers such as religious affiliation and skin colour, and limited information about national minorities such as the Sami or descendants of immigrants beyond the second generation.

A central premise for the present analysis is that the regulation of preferential treatment of ethnic minorities depends on the identification of appropriate target groups. As we have seen, the established theoretical understanding of ethnicity, derived primarily from the social anthropological literature, recognizes ethnicity as a collective identity that is socially negotiated. The boundaries between ingroups and out-groups are maintained through a continuous interplay between external and internal categorization, and related processes of inclusion and exclusion. This theoretical understanding of ethnicity coexists with a more common sense understanding of ethnicity as a term identifying a racialized, culturalized and inherently different 'other'. This article asks to what extent the Norwegian and Swedish documents rely on a theoretical or common sense understanding of ethnicity. Do they differ in this respect? How do these different understandings of ethnicity contribute to the identification of target groups for preferential treatment?

\section{Ethnicity - categorization and legal protection}

\subsection{Norway}

Legislation regulating ethnic discrimination and ethnic equality has emerged gradually in Norway and Sweden. Norway introduced a general ethnic equality law, the Discrimination Act, in 2005 (LOV2005-06-03-33). The Holgersen committee report (1) outlined and discussed the background for this legislative reform. In their report, the committee discussed the concept of ethnicity explicitly. The committee writes that the concept is not static, may change over time 
and will not mean the same thing in different contexts where it may be used. Referring to a book on multiculturalism in Norway by Social Anthropologists Thomas Hylland Eriksen and Torunn Arntsen Sørheim (1994), they argue that it is not possible to outline the boundaries of ethnicity clearly 'partly because 'ethnicity' is not something objective, but rather is subjectively experienced differences that are relevant in the interaction between people' (NOU 2002:12 section 3.4). ${ }^{1}$ At the same time, they define the concept broadly as follows: "Ethnicity" could be described based on the conditions that unite people as an ethnic group - that is, the conditions that are typical for a group's ethnic background' (NOU 2002:12 section 3.4.2.5). As examples of such conditions, they mention skin colour, race (based on perception of difference), religion, cultural characteristics such as clothing or language, as well as descent, kinship, geographical connection or trade and industry traditions. To a large extent, this definition is derived from and coincides with the established social anthropological understanding of the term.

From the perspective of the committee, the fact that 'ethnicity' has such a wide range of meanings makes it a particularly suitable concept for legislation. This is because, they argue, it will cover a variety of different cases that at the same time will be comparable to each other based on the same simple legal clauses. They suggest that the law should protect against ethnic discrimination without any further specification of grounds, and that religion should not be covered separately from ethnicity.

In the Government's white paper presented to the Parliament based on the Holgersen committee report, the Government disagrees with this conclusion and proposes that the implicit grounds covered by the act should be made explicit, and that religion should be covered separately from ethnicity (Ot.prp. nr. 33 (2004-2005)). The Government's decision was a response to the public consultation process, where many stakeholders (the Ministry of Justice, Centre against Ethnic Discrimination (SMED), the Norwegian Directorate of Immigration (UDI), the Gender Equality Ombud, to name a few) argued that 'ethnicity' was too vague and needed further specification (Ibid.: 85). As a result, the current objective of the Discrimination Act is to 'promote equality, ensure equal opportunities and rights and prevent discrimination based on ethnicity, national origin, descent, skin colour, language, religion or belief' (LOV-2005-06-03-33 section 1).

A few years after this law came into force, the Norwegian Government appointed the Graver committee (2) to work on a proposal for a comprehensive discrimination act that would unify and replace all the various anti-discrimination and equality regulations across grounds and areas of social life. In 2009, the proposal for a comprehensive discrimination act was presented by the Norwegian discrimination law committee (NOU 2009:14). The committee suggested that of the grounds protected by the Discrimination Act of 2005 , only ethnicity and religion or belief should be explicitly mentioned in the list of grounds. The other grounds - national origin, descent, skin colour and language - should not be listed explicitly and should only be covered as markers of ethnicity, that is, in relation to ethnic discrimination.

In their consultation response to this green paper, the Norwegian Centre against Racism (Antirasistisk Senter) objected to these proposed legal changes, arguing that skin colour and language in particular should be considered independent grounds. They write,

Skin colour does not always coincide with ethnicity. This is the case for many adopted children, but to an even larger extent for children of immigrants. Norway today has a large group of
Norwegians with dark skin. (...) [In] the future we will see an even bigger group of ethnic Norwegians with a different skin colour than the Norwegian majority (Antirasistisk senter, consultation response 28 December 2009).

This objection underscores the racialized framing of ethnic inequality in the committee's argumentation, in line with the common sense understanding of the term. The committee's association of skin colour with ethnicity seems to imply either that ethnicity is racialized to the extent that ethnicity is rendered meaningful through its association with skin colour, or, that having dark skin must be associated with some degree of foreignness. A third interpretation is that the term ethnicity in some cases simply functions as a euphemism for 'race', implicitly acknowledging the social reality of racial categorization without employing the controversial concept.

The earlier Holgersen committee (1) had suggested avoiding the term 'race' in the Norwegian discrimination act. The discussion on 'race' is relevant in order to understand the role ethnicity is meant to play in the legal texts relative to 'race', a concept more commonly used in other national contexts, for example, in the United States. They argued that the term is inappropriate, because it 'refers to biological, hereditary characteristics, according to theories without any justifiable foundation or content' (NOU 2002:12 section 3.4). At the same time, they acknowledged the existence of racism and contended that 'often a person that discriminates on the basis of ethnicity finds justification for their action in a belief that the person's own "race" is systematically superior to one or more other "races"" (ibid.). Therefore, they concluded that discrimination motivated by racism should be considered unlawful according to the law, without employing the term 'race' in the legal documents. Despite complaints from the UN Committee on the Elimination of Racial Discrimination (CERD), the subsequent Graver committee (2) agreed with this conclusion and maintained that racially motivated discrimination would be adequately covered by the legislation without the explicit use of the term 'race' in the legal text.

\subsection{Sweden}

The most recent ethnic equality legislation reform in Sweden was introduced in 2008 with the enactment of a comprehensive antidiscrimination and equality legislation, covering all legally protected discrimination grounds in a wide range of areas of social life. In their proposal for this new legislation, the Swedish discrimination law committee (4) defines ethnic background as denoting 'that someone belongs to a group of people that has the same national or ethnic origin, race or skin colour' (SOU 2006:22 p. 25). They do not venture into any further clarification or definition of the term 'ethnic origin'. However, in their discussion on preferential treatment, which I will come back to shortly, it is clear that the Swedish committee also understands the term to be associated with a broad and multifaceted set of meanings.

While they did not discuss the term ethnicity in further detail, the Swedish discrimination law committee (4) had a thorough discussion of the term 'race'. The committee was explicitly asked to explore the possible removal of the term 'race' from the legislation. Contrary to both of the aforementioned discrimination law committees in Norway, the Swedish committee concluded that the term should be kept in the legal texts.

The discrimination law committee (4) justifies their conclusion by arguing that in an international context race is considered to 
describe something different from skin colour and national or ethnic origin' (SOU 2006: 22, p. 308). They, therefore, recommend that it be included as a separate ground also in Swedish legislation. However, in the subsequent white paper to the parliament, the Swedish Government rejected the discrimination law committee's conclusion to retain the term 'race'. The Ministry of Integration and Equality that was in charge of proposing the legal changes, argued that including the term 'race' in the legal text 'could be seen as a legitimization of racist ideas and could cement race as an existing category' (Lagrådsremiss January 24 2008). As an alternative, they suggested to define ethnic background in an open-ended fashion as 'national or ethnic origin, skin colour or other similar circumstance', which became the final definition applied in the legal text (Diskrimineringslag 2008:567).

\section{Ethnic equality and preferential treatment}

\subsection{Norway}

The Norwegian Holgersen committee (1) was asked to 'carry out a comprehensive evaluation of existing laws and regulations, including civil and criminal law that directly or indirectly regulate the protection against ethnic discrimination. In this context, the committee should look to the gender equality law and seek to benefit from the experiences that have been made in that field' (NOU 2002: 12 section 1.1). In light of this, the committee proposed to allow preferential treatment of ethnic minorities. Yet, they only briefly discussed the potential challenges inherent in such a regulation. They acknowledged that preferential treatment of ethnic minorities is more challenging than the case is for gender, which was providing the template for their proposal. They wrote,

To a certain extent it involves (in the same way as the gender equality law) two groups, which would be persons with Norwegian ethnic background and persons with other ethnic background. At the same time this presents a skewed picture of the circumstances. Ethnic minorities cannot in the same way be viewed as a singular unit in relation to the question of preferential treatment. In many contexts there will be significant differences between ethnic groups regarding their overall situation, their degree of integration and participation in Norwegian society, which particular problems they encounter and what specific needs they may have for protection and accommodation (NOU 2002:12, section 13.6.2).

Furthermore, they suggested that it could be relevant to use preferential treatment in different ways and to an unequal extent in relation to different groups. As a consequence, they argued, individuals from one ethnic group could claim to have been unlawfully discriminated against because of the preferential treatment of an individual from another ethnic group. Having mentioned this, they went on to conclude that these challenges cannot be solved theoretically and must be left up to judicial practice. The committee did not at any point discuss whether preferential treatment of ethnic minorities should be restricted to some areas of social life such as education or the labour market. This makes the Norwegian legislation particularly vague on the topic of preferential treatment. In the consultation responses to the Holgersen committee green paper (1), several stakeholders asked for a more concrete elaboration of how access to preferential treatment of ethnic minorities should be used, among them the Centre against Ethnic Discrimination (SMED), The Contact Committee for Immigrants and the Authorities (KIM) and the Gender Equality Ombud. Yet, despite the vagueness, uncertainty and calls for specification, the Norwegian government decided to allow preferential treatment of ethnic minorities in all areas of social life in the Discrimination Law of 2005, a conclusion that went undisputed through the most recent discrimination law committee's deliberations in the NOU 2009:14 document (2).

\subsection{Sweden}

The 1997 advisory committee (3), proposing the first law against ethnic discrimination in Sweden that included positive action measures, had a brief and inconsistent discussion about who should be covered (SOU 1997:174). The committee argued on the one hand that it should be possible to compare the relevant populations with available statistics, but on the other hand that it would be preferable if the employees self-identified, and that this should be voluntary (SOU 1997:174, pp. 239-242).

The subsequent discrimination law committee (4) was given a specific mandate to deliberate on the issue of allowing preferential treatment for ethnic minorities. The committee presents a relatively lengthy discussion about how to define who should be covered by the regulations and in which areas of social life this kind of positive action would be relevant. They explicitly compare preferential treatment based on ethnicity with preferential treatment based on gender. They write that preferential treatment for gender is relatively easy to design and carry out because the term divides people into two categories that can be distinguished quite easily by name, looks or social security number (which in Sweden and Norway is gender coded). By contrast, when it comes to ethnic background 'there are many more categories than two. How many ethnic backgrounds or groups there are is impossible to say. The number is big. It can also be assumed to be changing in a changing world' (SOU 2006:22, p. 655).

The discrimination law committee (4) sketched out the following scenarios that were meant to exemplify the complexity of the question of target groups: If the criterion is being foreign born or having foreign born parents, then for example Norwegians would be covered and Sami people would not. If the criterion is to have grown up in a place with another culture than Scandinavian culture, then a non-immigrant growing up in an immigrant dense neighbourhood could be covered. If the criterion is having a mother tongue other than the Nordic languages, then it is not clear who would be covered (SOU 2006:22, p. 655). Whether one or two foreign born parents should count was also problematized:

[Using two foreign born parents] would mean that a person whose parents come from a country that is culturally and economically similar to Sweden in Western Europe, for example Germany, would be considered. A person whose father is ethnically Swedish and whose mother is from Africa would however not be considered. If we further add to the circumstances that the parents separated at an early age, and that the person lived alone with his or her non-Swedish born mother from he or she was very young, a picture emerges where many probably would agree that the person's social and economic conditions 'should' qualify him or her for preferential treatment to a greater extent than a person whose parents come from Germany (SOU 2006:22, p. 656). 
Here, the intersection of ethnicity and social class is alluded to but not discussed further. However, the example indicates that some groups may be seen as more 'deserving' of preferential treatment than others, depending on their distance from a white middle class norm.

When the committee moves from discussing preferential treatment in the labour market to discussing whether to allow preferential treatment of ethnic minorities in education, they begin to explicitly address the complex intersection of ethnicity and social class. Yet in this discussion, they seemingly come to the opposite conclusion regarding appropriate target groups. The committee refers to research showing that immigrants and children of immigrants are underrepresented at institutions of higher education mainly because of their socioeconomic background (SOU 2006:22, p. 682). The committee concludes that in terms of preferential treatment in education, ethnicity poses two problems. First, it is a challenge to decide the criteria by which ethnicity should be defined and a question of how to register the information without infringing on people's right to privacy. Second, if inequality in access to education for ethnic minorities is caused by their socioeconomic position, preferential treatment is not the right answer. Then, other programmes should be invested in that would help all persons from disadvantaged socioeconomic backgrounds, while at the same time being sensitive to the specific difficulties of ethnic minority youth (SOU 2006:22, p. 685). The committee argues that there is a difference between education and the labour market in this respect and proposes to allow preferential treatment only in the labour market.

A minority of the committee members, including the committee leader Göran Ewerlöf, explicitly disagreed with this conclusion. These committee members present five arguments against the majority's position: (1) Preferential treatment always entails discrimination and is therefore fundamentally problematic. (2) It would be a voluntary measure and does not have support among the social partners; therefore it would not be effective. (3) According to EC regulations, it is restricted to instances where qualifications are comparable, which means that it will have limited practical impact. (4) It is uncertain which groups or individuals should be covered by the law, which could result in reduced security under the law for employers. (5) A condition for allowing preferential treatment is that it should contribute to promoting equal opportunities regardless of ethnic background, and that it should be discontinued when equality has been reached. In practice, this demands that the employers collect and analyse statistics on both their own workers and the relevant recruitment base. This would involve a breach of the right to privacy and would be difficult and time consuming to carry out. As a conclusion, the dissenting minority group argues that the disadvantages of allowing preferential treatment outweigh the potential benefits. According to the statement, the decisive factor for their conclusion is the uncertainty regarding who should be covered by the law (SOU 2006:22 Reservations, p. 532).

In their white paper to the parliament, the Swedish Government supported the minority's position and concluded that preferential treatment for ethnic minorities should not be permitted (Lagrådsremiss January 24 2008). The Government's decision was also influenced by the fact that an overwhelming number of consultation letters expressed scepticism on the green paper's conclusion. The white paper stated that allowing one individual's opportunities to be compromised by favouring another individual should be accompanied by strong justification and careful consideration (Lagrådsremiss January 24 2008, p. 167). In line with the discrimination law committee's minority statement, the government referred to the practical challenges associated with preferential treatment of ethnic minorities. The first practical challenge they pointed to was the difficulty in defining appropriate target groups. Other practical challenges mentioned were registration of sensitive information, and the need to continuously monitor the ethnic composition of work force and the recruitment base. As a result, the Swedish discrimination law currently does not permit preferential treatment of ethnic minorities.

\section{Concluding discussion}

The Norwegian discrimination law committees defined ethnicity in a relatively open-ended and inclusive fashion, acknowledging to a large extent the established complex theoretical definitions of the term, derived from the discipline of social anthropology. They recognized that the concept has a range of meanings such as subjectively experienced differences, cultural and socially defined reference markers, and that there are big differences between ethnic groups regarding their position in Norwegian society.

The Swedish discrimination law committees did not explicitly discuss the concept of ethnicity, but drew some distinctions in their discussion of the practical challenges inherent in defining target groups for preferential treatment. Their examples covered place of birth, parents' place of birth, language, culture, traditions and identity. They also discussed the issue of 'race', which they suggested has connotations that do not completely align with the concept of ethnicity.

The analysis of the policy documents indicate that to move from a theoretical understanding of ethnicity as social categorization to concrete examples of individuals or groups, the broad theoretical definition must give way to more common sense understandings of ethnicity as denoting 'foreign' or 'other'. We saw this for example in the Swedish deliberations, when the legitimacy of using 'born abroad' as a criterion is questioned because it would encompass Norwegians. Norwegians are clearly not foreign enough. Similarly, we saw it in the Norwegian proposal to only cover skin colour as a marker of ethnicity, as if ethnic Norwegians cannot have dark skin.

In both countries, the conclusions of the independent advisory committees regarding the content of the term ethnicity, and the way it was suggested specified in the legal text, were contested by stakeholders and policy makers. In both cases, the final legal texts differed from the legal texts proposed by the committees. This underscores the lack of consensus regarding how ethnicity should be understood as a legal category. At the same time, the political process led to diametrically opposed conclusions regarding access to preferential treatment of ethnic minorities in the two countries. While the Norwegian legislation allows preferential treatment of ethnic minorities in all areas of social life, the Swedish legislation currently does not allow preferential treatment of ethnic minorities at all.

Because the Swedish law is organized in chapters that separately cover the labour market, education, access to goods and services etc. (cf. Borchorst et al. 2012; Reisel 2014), the Swedish discrimination law committee had to explicitly evaluate the issue of preferential treatment in different areas of social life. They came to the conclusion that the mechanisms that disadvantage ethnic minorities in the labour market are different from the mechanisms that disadvantage ethnic minorities in the education system. That is, ethnic minority students are underrepresented in higher education primarily because they disproportionately come from working class backgrounds. Since there are no systematic differences in class origin between men and women, this argument cannot be raised regarding preferential treatment on the grounds of gender. With regard to gender, equality is simply operationalized as an appropriate percentage men or women. The Swedish discrimination law committee's discussion 
about one versus two foreign born parents, comparing a person with two German born parents and a person with an African mother and an absent Swedish father, reveals that there is an underlying tension in the Swedish discourse with regard to what would be a 'fair' outcome of preferential treatment of ethnic minorities. The tension derives from the simultaneous application of two competing frames; that of 'othering' and that of 'equality'. To normatively evaluate what constitutes ethnic equality, it is necessary to identify the relevant target groups. Yet the identification of 'appropriate' target groups depends on tacit common sense understandings of difference or 'otherness', which is not articulated in the policy documents.

Through their efforts to exemplify the practical challenges and specify the underlying mechanisms at work in different areas of social life, the Swedish committee also opened up for contrasting views. By contrast, it is difficult to say anything substantive about how the Norwegian discrimination law committees conceptualize ethnic equality on the basis of the policy documents analysed here. It is therefore particularly interesting that the Norwegian government decided to allow this relatively controversial measure, without much discussion. One interpretation of this mismatch is that the question carries normative weight and plays into the kind of identity politics that Marianne Gullestad (2002) referred to regarding the polarized rhetoric of the immigration debate. From this perspective, signalling clear support for ethnic equality becomes more important than a thorough debate. As a consequence, the potential challenges of implementation receive relatively little attention in the documents.

The present analysis suggests that ethnicity must be interpreted through a multifaceted unarticulated common sense lens of 'othering' in order to identify appropriate target groups for preferential treatment. However, this interpretation process is not made explicit, which leaves unanswered the important question of how to recognize ethnic equality, or even progress towards such a goal. It may be practical to define ethnicity as broadly as possible for the purpose of tackling a variety of complaints cases. However, when it comes to proactive work, exemplified here by access to preferential treatment, such a broadly defined concept of ethnicity cannot be directly utilized. One implication of this finding is that in order for proactive measures to be effective in changing ethnic inequality in the labour market, it is particularly crucial to implement structures that clearly allocate responsibility to specific individuals or committees within the work places and institutions where the law applies. One of their responsibilities should be to make explicit exactly which target groups are seen as relevant to the specific organization, and by which criteria the organization would conclude that ethnic equality has been reached.

\section{Acknowledgements}

This research was carried out as part of the project 'Multidimensional equality - Legislative reforms and judicial practices', funded by the Research Council of Norway through the Programme for Gender Research (project number 189074).

Liza Reisel is a senior research fellow at Institute for social research in Oslo, Norway. Her main research fields are social stratification, education, race/ethnicity and gender equality. Her two most recent publications are Reisel, L. (2013). 'Mot et flerdimensjonalt likestillingsapparat' (Towards a multidimensional equality apparatus), Chapter 4 in Beret Bråten and Cecilie Thun (eds.) Krysningspunkter: Likestillingspolitikk $\mathrm{i}$ et flerkulturelt Norge (Intersections: Equality politics in a multicultural Norway) and. Reisel, L. (2014) Legal Harmonization and Intersectionality in Swedish and Norwegian Anti-discrimination Reform, Social Politics: International Studies in Gender, State and Society, 21 (2).

\section{Notes}

1 All quotes from the policy documents are translated from Swedish or Norwegian to English by me.

\section{References}

Bacchi, CL 1999, Women, policy and politics: the construction of policy problems, Sage Publications, London, Thousand Oaks, New Delhi.

Barth, F 1969, Ethnic Groups and Boundaries: The Social Organization of Cultural Difference, Universitetsforlaget, Oslo.

Borchorst, A, Freidenvall, L, Kantola, J, Reisel, L \& Teigen, M 2012, 'Institutionalizing Intersectionality in the Nordic Countries? AntiDiscrimination and Equality in Denmark, Finland, Norway and Sweden' in Institutionalizing Intersectionality? Comparative European Analyses, eds A Krizsan, H Skjeie \& J Squires, Palgrave Macmillan, Basingstoke.

Bowen, WG \& Bok, D 1999, The shape of the river: Long-term consequences of considering race in college and university admissions, Princeton University Press Princeton, NJ.

Bowen, WG, Kurzweil, MA \& Tobin, EM 2005, Equity and excellence in American higher education, University of Virginia Press.

Collins, H 2003, 'Discrimination, Equality and Social Inclusion', The Modern Law Review, vol. 66, no. 1, pp. 16-43.

Edelman, LB, Petterson, S, Chambliss, E \& Erlanger, HS 1991, 'Legal ambiguity and the politics of compliance: Affirmative action officers' dilemma', Law \& Policy, vol. 13, no. 1, pp. 73-97.

Eriksen, T H 2002, Ethnicity and nationalism: Anthropological perspectives. Pluto Press.
Fredman, S 2001, 'Equality: A New Generation?', Industrial Law Journal, vol. 30, no. 2, pp. 145-168.

Garces, LM 2012, 'Racial Diversity, Legitimacy, and the Citizenry: The Impactof Affirmative Action Bans on Graduate School Enrollment', The Review of Higher Education, vol. 36, no. 1, pp. 93-132.

Gullestad, M 2002, Det norske sett med nye øyne: kritisk analyse av norsk innvandringsdebatt, Universitetsforlaget, Oslo.

Gunaratnam, Y 2003, Researching 'Race' and Ethnicity: Methods, Knowledge and Power SAGE Publications Ltd, London, UK.

Hall, S 2000, 'Conclusion: The multi-cultural question' in Un/settled Multiculturalisms: Diasporas, Entanglements, Transruptions, ed B Hesse, Zed books, London, pp. 209-241.

Heath, A 2014, 'Affirmative action policies to remedy ethnic minority disadvantage in the labour market'.

Hepple, B 2004, 'Race and Law in Fortress Europe', The Modern Law Review, vol. 67, no. 1, pp. 1-15.

Hylland Eriksen, T \& Sørheim, TA 1994, Kulturforskjeller i praksis: Perspektiver på det flerkulturelle Norge, Ad notam Gyldendal, Oslo.

Jenkins, R 1997, Rethinking Ethnicity: Arguments and Explorations, SAGE Publications, London, Thousand Oaks, New Delhi.

Kalev, A, Dobbin, F \& Kelly, E 2006, 'Best practices or best guesses? 
Assessing the efficacy of corporate affirmative action and diversity policies', American sociological review, vol. 71, no. 4, pp. 589-617.

Mason, L 2010, 'The Hollow Legal Shell of European Race Discrimination Policy: The EC Race Directive', American Behavioral Scientist, vol. 53, no. 12, pp. 1731-1748.

NOU 2002:12, Rettslig vern mot etnisk diskriminering, Norges Offentlige Utredninger, Kommunal- og Regionaldepartementet, Oslo.

NOU 2009:14, Et helhetlig diskrimineringsvern, Norges Offentlige Utredninger, Barne- og Likestillingsdepartementet, Oslo.

Reisel, L 2014, 'Legal Harmonization and Intersectionality in Swedish and Norwegian Anti-discrimination Reform', Social Politics: International Studies in Gender, State \& Society, vol. 21, no. 2.

Ridgeway, CL 2011, Framed by Gender:How Gender Inequality Persists in the Modern World, Oxford University Press, New York.

Schömer, E 2012, 'Multiple discrimination. A smokescreen over differences', Retfærd, vol. 3, pp. 29-50.
Simon, P 2012, 'Collecting ethnic statistics in Europe: a review', Ethnic and Racial Studies, vol. 35, no. 8, pp. 1366-1391.

Skjeie, H 2009, 'Multiple equality claims in the practice of the Norwegian anti-discrimination agencies' in European Union Non-discrimination Law. Comparative perspectives on multidimensional equality law, eds D Schiek, D \& V Chege, Routledge Cavendish, London and New York.

SOU 1997:174, Räkna med mångfald! Förslag till lag mot etnisk diskriminering i arbetslivet m.m., Statens Offentlige Utredningar, Inrikesdepartementet, Stockholm.

SOU 2006:22, En sammanhållen diskrimineringslagstiftning, Statens OffentligeUtredningar, Regeringskanslietsförvaltningsavdelning, Stockholm.

Weber, M 1978, Economy and Society: An Outline of Interpretive Sociology, University of California Press, Berkeley and Los Angeles. 